\title{
Engagement, bonding, and identity across multiple platforms: Avaaz on Facebook, YouTube, and MySpace
}

\section{Anastasia Kavada}

MedieKultur 2012, 52, 28-48

Published by SMID | Society of Media researchers In Denmark | www.smid.dk The online version of this text can be found open access at www.mediekultur.dk

This article explores the role of social media platforms in transnational activism by examining the case of Avaaz.org, an international advocacy organization aiming to bring people-powered politics to global decision-making. Focusing on the Avaaz website, its channel on YouTube, its page on Facebook and its profile page on MySpace, the article investigates the affordances of these platforms for identity-building, bonding, and engagement. The empirical data is derived from features analysis of the selected web platforms, as well as textual analysis of the comments posted by users. The findings show that while social media platforms make individual voices more visible, their design helps Avaaz to maintain a coherent collective voice. In terms of bonding, platforms allow individual activists to communicate with the organization and to spread its message to their existing social networks, but opportunities for private interpersonal communication with other Avaaz supporters are limited.

\section{Introduction}

With their emphasis on peer production, collaboration, and interaction (O'Reilly, 2004), social media platforms have the potential to invigorate political participation. They provide activist organizations with access to new audiences and allow them to spread their messages to the users' existing social networks. This potential, however, is placed into question 
by the risks of surveillance (Morozov, 2011), as well as the commercial character (Andrejevic, 2011) and design of such platforms, which is aimed at fostering individual rather than collective creativity (Fenton \& Barassi, 2011).

This article investigates the uses of web platforms for transnational activism by examining the case study of Avaaz, an international advocacy organization that represents a new form of internet campaigning. Focusing on the organization's own website and its presence on Facebook, YouTube, and MySpace, the study explores the affordances of each platform for identity-building, bonding, and engagement. To set the background for this analysis, the following sections discuss the case of Avaaz within the broader context of transnational activism and outline a conceptual framework for investigating the affordances of web platforms for activist organizations.

\section{Social media and transnational activism}

The late 1990s have marked a new era for transnational activism. In contrast to centralized and NGO-dominated policy networks, this second-generation activism is characterized by "sprawling, loosely interconnected network webs" (Bennett, 2005, p. 213) with limited central command. The agenda of these networks is increasingly "set from below", allowing individual activists more direct involvement in decisions over political goals. This secondgeneration activism is also distinctly multi-issue, pursuing a diversity of permanent campaigns "with less clear goals and political relationships with targets" (ibid., p. 212).

Against this backdrop, organizations like Avaaz represent a hybrid form of transnational activism (Chadwick, 2007), combining some second-generation characteristics with those of more traditional advocacy organizations. According to its website (www.avaaz.org), Avaaz is a new "global web movement" founded in January 2007. Its aim is "to bring peoplepowered politics to international decision-making" by articulating global public opinion. Meaning "voice" in Urdu, Hindi, and other Asian, Middle Eastern, and Eastern European languages, its name accurately conveys this mission. The Avaaz strategy involves rapid response to urgent problems by mobilizing large numbers of subscribers to donate small amounts of money or sign petitions. As of September 2011, Avaaz has undertaken more than 50 million actions while its membership counts almost 9.73 million participants.

Its campaigns bridge local concerns with global issues and have focused on a wide range of issues that are in the media spotlight. These have included peace in the Middle East, climate change, the Burma uprising, and the Iraq war. Avaaz often pursues campaigns in coalition with other organizations or coordinates actions in support of different social movements. For instance, Avaaz recently aided activists in the Arab world by training citizen journalists and providing them with technologies to report on the Arab Spring. They also mobilized in support of the Occupy movement by fundraising for a global opinion poll, aiming to show public support for the movement's demands. 
Co-founded by MoveOn, Res Publica, and GetUp.org.au, Avaaz replicates the organizing model of its founders on an international level. It is coordinated by a small professional team of campaigners based in four different continents, while the headquarters of the organization are in New York City. Thus, Avaaz is more centrally controlled than the campaign networks of "second generation" transnational activism. Campaigners are responsible for defining the priorities of Avaaz and for developing its messages with the help of expert advisors. These priorities are also set through opinion polls of the Avaaz membership base. Ideas for campaigns are tested on 10,000-member random samples and only those that garner strong support are forwarded to the full membership. This emphasis on polling and testing fulfils what Avaaz calls "an ethic of servant leadership" (www.avaaz.org), with staff members responsible for listening to the membership base and crafting actions in response to its concerns, rather than setting the agenda in advance.

This mode of functioning would not be possible without the use of the internet. As a "web movement", Avaaz operates predominantly as a virtual organization. Its core tool is an email alerts list that operates in 14 languages. Avaaz also has a website available in 15 languages and occupies a wide range of social networking and content sharing sites, including Facebook, MySpace, YouTube, and Flickr. The internet facilitates the ability of Avaaz to mobilize large numbers of participants by lowering the costs of communication, since sending an email to thousands of recipients costs the same as contacting only one (Della Porta $\&$ Mosca, 2005). The presence of the organization on social networking sites offers access to new audiences and allows for its actions to scale up, as they can be easily advertised by supporters to their own networks. Digital and social media thus help Avaaz to organize broad mobilizations with a simple and lightweight structure.

In turn, the lower operating costs allow for a fundraising strategy that focuses on specific targets, such as getting a television spot on air (Karpf, 2009). In a manner similar to its predecessor MoveOn, this aids Avaaz in raising money quickly and efficiently. The organization does not accept funding from sponsors or governments and has started only recently to solicit regular donations from members, aimed at sustaining the organization. As of February 2012, Avaaz had garnered nearly 22,000 weekly "sustainers" who agreed to contribute a small amount of money per week to support the organization.

Avaaz's mobilization efforts concentrate mainly on simple online actions or "actionable chunks" (Boyd, 2003). This broadens the appeal of the organization and facilitates those with limited time and resources to make frequent but small contributions. It is a strategy that could only work well in the internet era, at a time when digital communication technologies have rendered the aggregation of massive numbers of individual contributions an easy process (Chadwick, 2009). The speed of internet communication also helps the organization to rapidly shift its focus to issues that dominate public debate, allowing Avaaz to take advantage of the momentum around specific events.

Yet, like MoveOn, Avaaz can be criticized for lowering the bar of participation. The organization operates on a lax definition of membership, whereby subscribers to its email alerts 
list are considered to be members. This means that people can leave Avaaz as easily as they joined. In his analysis of MoveOn, Karpf (2009) has discussed a similar problem noting that "the low barrier-to-entry for organizational membership yields a large-but-questionable base of recipients" (p. 15). Designed as a form of activism for busy people with few minutes to spare, Avaaz also demands little commitment from its members and makes it difficult to build a sense of community (Kavada, 2010a).

Nevertheless, Avaaz's presence on social networking and content-sharing sites multiplies the potential of communication with its participants. It can also provide more opportunities for interaction among Avaaz supporters, helping to build ties of solidarity (Kavada, 2010b). Treating users as co-producers rather than consumers of content (O'Reilly, 2004), such platforms can enable Avaaz participants to contribute more directly to the agenda of the organization.

Social media platforms can also stimulate mobilization through the use of pre-existing social networks. According to social movement theory, to become involved in movement activities, people need to share the movement's beliefs, be targeted by mobilization efforts, become motivated to take action, and overcome barriers of participation (Klandermans, 1997). Social media can facilitate many of these steps. As spaces used mainly for socializing with friends, they can become entry points to activism for individuals with limited political experience. Social media users can easily become the targets of mobilization efforts when "friends" forward or broadcast messages about specific campaigns. Such technologies can also facilitate "shared awareness", i.e., "the ability of each member of a group to not only to understand the situation at hand but also to understand that everyone else does, too" (Shirky, 2011, pp. 35-36). This can strengthen mobilization, as seeing the support of others for the same campaign enhances the perception that the campaign will be successful (Kavada, 2010b). Social media sites may also lower barriers to participation, as they help in organizing the practicalities for taking action.

Yet, the potential of social media platforms for mobilization is currently a contested issue. Authors like Gladwell (2010) and Morozov (2011) warn of the risks of "clicktivism" or "slacktivism", arguing that simple online actions constitute a fleeting and shallow type of participation. For Gladwell (2010), online communication is only able to build weak ties between action participants, which are not enough to motivate supporters to take to the streets. The effectiveness of such tactics in terms of real policy change, as well as the threat of surveillance and repression (Morozov, 2011) are also matters under dispute.

Other concerns regard the capacity of social media platforms to foster a sense of collective identity. Fenton and Barassi (2011) note that debates on the democratic potential of such technologies tend to focus on individual agency, disregarding "how the self-centred forms of communication that these platforms enable can challenge rather than reinforce the collective creativity of social movements" ( $p .180$ ). They suggest that the proliferation of individual voices on social media can stifle organizational messages. Social media platforms are also governed by an ideology that emphasizes individual over collective creativity. 
This often serves to conceal how the users of such platforms - the content they produce and their personal data - are turned into commodities in the service of corporate interests (Andrejevic, 2011).

User-generated content may further weaken the organization's control over its image and confuse its message (Gueorguieva, 2008). Social media thus present political organizations with a dilemma "between a desire to maintain control over messages and resources and the generally decentralizing dynamic of Web-based communication" (Foot \& Schneider, 2006, p.6). This is often solved by eschewing the more interactive aspects of the technology. For instance, in their study of the British anti-war movement, Gillan et al. (2008) have demonstrated that the inability to control the quality of discussions limited the adoption of interactive features. Moderating comments and managing the interaction on different platforms is also a resource-intensive process and impossible to sustain for some organizations (Fenton \& Barassi, 2011).

The organization's presence on multiple platforms can also fragment its membership base and complicate the process of communicating with its participants. Baym (2010) terms this phenomenon "networked collectivism", i.e., "meaning that groups of people can now network throughout the internet and related mobile media, creating a shared but distributed group identity" (p. 91). Yet, contrary to the more unified collective identities of initial online communities, networked collectivism "challenges many of the qualities that can make these groups cohere into something more than the sum of their parts" (ibid., p. 91).

Conversely, it may be exactly this emphasis on individual autonomy and creativity that makes social media so useful for current movements. Bennett and Segerberg (2011) note a growing individualization of political participation that results from broad trends associated with globalization, the relation between the individual and the state and the growing appeal of lifestyle politics. Within this context, "[c]ommunication technologies aimed at personalizing engagement with causes facilitate organizational communication and coordination at the same time as they enable flexibility in how, when, where, and with whom individuals may affiliate and act" (Bennett \& Segerberg, 2011, p. 771). They may therefore allow organizations to balance the competing demands for personalized activism and organizational coherence that characterize current political participation.

Yet, for all the intense debate on the political potential of social media, empirical evidence on whether and how they affect political participation is lacking. As Segerberg and Bennett (2011) put it, "[a]s long as the debate remains anchored in anecdotal evidence and sweeping generality, there is little reason to believe that we are analysing social deployments of technology adequately, let alone establishing decidable grounds for assessing their effects" (p. 199). To do this, we need to move away from an either/or logic that considers social media as substituting rather than complementing other forms of communication. Perceiving social media as part of an organization's communication ecology can offer a more nuanced picture. For example, in my previous research on the Global Justice Movement, I showed that while email lists were indeed connected with dynamics of individual 
autonomy and dispersion, face-to-face meetings reinforced a sense of belonging and collective identity. The two communication spaces were also closely interlinked, as email lists were used to organize physical meetings, while convening face-to-face invigorated traffic on the email lists (Kavada, 2010a).

In addition, studies need to take into account that social media platforms differ in their design, purpose, norms, and rules of regulation, which in turn affect their potential for engagement and solidarity. This latter issue constitutes the main focus of this article. To offer a solid basis for this enquiry, the following section presents a conceptual framework for studying the role of web-platforms in bonding and identity-building.

\section{Web platforms, bonding, and group identity}

Web platforms can be viewed in two complementary ways. Firstly, they constitute representations of the organization and, secondly, they serve as spaces of interaction among the organization, its supporters, and peers. Borrowing terms from Taylor and Van Every (2000), this article considers web platforms as the surface and site of bonding and group identity.

The surface dimension relates to the image of the organization. In this dimension, the presence of the organization on the platform is treated as an imprint of the organization's activity and as a "text" that represents its identity. This is produced both by its official representatives and by its supporters and peers. Studies focusing on the presentation of self in social networking sites have invariably stressed the "network aspect" of the profile, where the display of connections is as crucial as the users' self-descriptions (boyd, 2006; Donath, 2008; Livingstone, 2008; Papacharissi, 2009). For instance, in a study of teenagers' use of social networking sites, Livingstone (2008) found that in some cases "position in the peer network was more significant than the personal information provided, rendering the profile a place-marker more than a self-portrait" (p. 399, emphasis added).

Extending these insights to organizational communication, this article considers "selfdisplay" to be the information generated by official representatives of the organization. The "public display of connections" consists of representations of the organization's supporters and of their relationship with the organization and with their fellow supporters. If, as boyd (2006) argues, individuals are "who they know" on social networking sites, organizations are "who supports them", but this image is also affected by the content added by their supporters on the organizational profile.

Investigating these platforms as a site of interaction turns our attention to the ways in which they frame group communication. Who communicates with whom and where this communication is located in the continuum between personal and impersonal, private and public, reciprocal and one-way are important for bonding and the development of a shared identity.

"Who communicates with whom" draws the boundaries, real or imaginary, of the group. This provides insight into the composition of the group that is engaged in the process of col- 
lective identity-building (Kavada, 2009). In this respect, it is worth keeping in mind that the locus of collective identity varies (Snow, 2001). Shared identities can refer to all supporters of the organization or flourish among a sub-group interested in a specific cause. Observing "who communicates with whom" further elucidates the process of bonding by helping to identify who is developing ties with whom. Establishing the context of the interaction and identifying the group or pair that is communicating depends on the technical infrastructure and rules of the platform. It is also a function of the modes of address employed by users and of the audiences that they have in mind when they are speaking. In this sense, the group includes everyone who is "simultaneously being acknowledged as hearing a speech act" (Austin quoted in Holmes, 2005, p. 108). Identifying who is the "you", "us", and "I" that are referred to in public communication is therefore crucial for understanding "who is communicating with whom".

Furthermore, reciprocity and interactivity are important both for bonding and for the development of a collective identity. The latter requires a process of "interactive broadcasting" (Etzioni \& Etzioni, 1999) enabling participants to send messages that reach many people simultaneously and allowing those who are addressed by the broadcast to provide feedback not only to the "broadcaster", but also to other recipients. Etzioni and Etzioni (1999) call the latter "communal feedback", noting that it is central for "mutual persuasion", the process through which people with different opinions come to develop a shared position. In other words, constructing a shared identity requires modes of communication that include many-to-many, one-to-many, and many-to-one.

Bonding, on the other hand, necessitates one-to-one communication that can provide a high level of encompassing knowledge of others (ibid.). Being able to authenticate the information that one receives and to hold others accountable are vital for the development of ties. In their analysis of collective action as a communicative phenomenon, Flanagin et al. (2006) note that for strong ties to be created, activists need personal interaction. This "involves repeated, organized interaction with known others over time and the development of interpersonal relations" (ibid., p. 33). Impersonal interaction, on the other hand, "emphasizes the expression or pursuit of interests and concerns" (ibid., p. 33), but does not involve any personal and direct interaction with others. This is more suited to "affiliative" ties that develop when individuals feel a sense of connection as a result of their shared affiliation to the organization.

The design of platforms, as well as their norms, rules, and regulations, structure their potential as a "site" and "surface" of bonding and identity. Including formal policies, requirements for membership and modes of governance, the rules of communication influence who communicates with whom and who has access to which information. They also affect how users interact, specifying the "style of communication between participants, accepted conduct, and repercussions for non-conformance" (Stanoevska-Slabeva, 2002, p. 75). The rules are encoded in the software supporting the platform (Noveck, 2005) and/or formally stated in documents governing its use, such as community standards, and terms of ser- 
vice agreements (Grimes, Jaeger \& Fleischmann, 2008). Platforms also provide different elements for interaction and self-representation and operate on specific logics when it comes to "friending" or the generation of content by users.

Yet, while web platforms influence the development of ties and a shared identity, they do not determine them. Instead, web platforms should be seen as offering "online structures" that enable and constrain online action (Foot \& Schneider, 2006). The concept of "affordances" can be useful here, as it represents a "third way" between technological determinism and social constructivism (Hutchby, 2001b). Following Gibson, Hutchby (2001a) defines affordances as the possibilities that different technological artefacts offer for action. In this sense,

...the uses and the 'values' of things are [...] a material aspect of the thing as it is encountered in the course of action. We are able to perceive things in terms of their affordances, which in turn are properties of things; yet those properties are not determinate or even finite, since they only emerge in the context of material encounters between actors and objects (ibid., p. 27).

Although Hutchby (2001b) stresses the relational character of affordances, this conceptualization seems to be lost when he describes affordances as properties of technologies and not of the relationship between actors and these technologies (Bloomfield et al., 2010). In this article, the concept of "affordances" is used with the latter in mind. Thus, the material or design characteristics of social media platforms enable and constrain their use by different actors. However, these affordances also depend on the skills, goals, and culture of their users who may employ platforms in ways that were not expected or intended by their designers.

\section{Methods and research questions}

In this article, web platforms are examined both as a "site" and "surface" of bonding and group identity. The study explored the following questions:

- How is the organization's image constructed on every platform?

Which are the components making up this representation?

Who shapes this representation and whose voice is more dominant?

- What are the affordances of each platform for the process of bonding and collective identity-building?

To answer these questions, the analysis focuses on Avaaz's page on Facebook, profile on MySpace, and channel on YouTube, as well as the English version of the main website. All of these materials were saved and archived on the $15^{\text {th }}$ of August 2009. The empirical results derive from an analysis of the platforms' features and textual analysis of users' comments. 
Features analysis is a type of web content analysis that focuses on recording the occurrence of particular features or characteristics of the website rather than words or themes. These features may include the types of information available on the website, types of links, interactive features such as opinion polls, as well as types of action that users can undertake on a website, such as signing petitions. Features analysis was one of the methods used by Foot and Schneider (2006) for studying the role of websites in the US election campaigns of 2000, 2002, and 2004. Foot and Schneider's coding scheme served as the starting point for the analysis presented in this article, but had to be adapted to capture features that are specific to social media platforms, such as Facebook "Likes". To provide a more comprehensive image of the interaction dynamics on the platform - its "site" characteristics - the features analysis also included categories about the "audiences" and "communicators" for each feature, as well as the types of communication that they tended to generate (one-way/reciprocal, private/public etc.). Again this reflects the more "platform" aspect of current websites and social network sites, where different types of users can be simultaneously "communicators" and audiences of each other's messages.

To investigate how Avaaz supporters were interacting on the website and on social media, I also analysed 400 comments posted on these four spaces. These included the 100 latest comments (on the $15^{\text {th }}$ of August 2009) on the "Comments and Advice" section of the main website and on the organization's walls on Facebook, MySpace, and YouTube. Comments can be perceived here as remnants of the users' activity on the platform. Although their representativeness may be questioned, comments can still offer insight into how users employ the platforms to build ties with the organization and other supporters and to perform their role as citizens. They also help us "assess in which context they assume their performance takes place and becomes meaningful" (van Zoonen et al., 2010, p. 253). I employed grounded theory to identify different types of comments based on their main function (e.g., expressing support, suggesting campaigns, thanking the organization for its work, etc.). The preliminary phase consisted of coding 15 comments per platform, keeping detailed notes about their themes. Categories were then developed using the "constant comparison method" (van Zoonen et al., 2007).

Textual analysis was also employed to investigate how users were positioning themselves with regards to Avaaz and to other supporters, as well as the modes of address and implied audiences of their comments. I paid particular attention to the words they used to refer to Avaaz and to other supporters and to the implied meanings of words like "us", "we", and "I". The results of this analysis are presented in the two following sections.

\section{Platforms as a surface of bonding and group identity}

This section discusses the representation of the organization by treating the four platforms as "text" and by investigating the elements that make up the identity of the group and the balance between individual and collective voices. 


\section{Self-display}

Table 1 focuses on the components of Avaaz's self-description on the four spaces. These are produced by the Avaaz campaigners and refer to the organization's mission, campaigns, and action. As the table shows, all of the online spaces occupied by Avaaz include a mission statement or "blurb". However, the Avaaz website constitutes the main point of reference for information about the organization, as it comprises a longer mission statement and provides the names and location of the Avaaz core team.

\begin{tabular}{|c|c|c|c|c|}
\hline & Main Website & MySpace & Facebook & YouTube \\
\hline 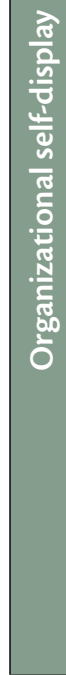 & $\begin{array}{l}\text { Mission } \\
\text { Our Team } \\
\text { Slogan } \\
\text { Number of Actions } \\
\quad \text { taken } \\
\text { Campaigns Info } \\
\text { Videos } \\
\text { Press Releases } \\
\text { Blog }\end{array}$ & $\begin{array}{l}\text { Blurb - Mission } \\
\text { Status Update } \\
\text { Location } \\
\text { Purpose of joining } \\
\text { Pictures } \\
\text { Videos } \\
\text { Blog }\end{array}$ & $\begin{array}{l}\text { Mission } \\
\text { Status Update } \\
\text { Slogan } \\
\text { Date Founded } \\
\text { Website URL } \\
\text { Links to other social } \\
\quad \text { networking and } \\
\text { content sharing } \\
\quad \text { sites } \\
\text { Wall comments } \\
\text { Notes } \\
\text { Campaigns Info } \\
\text { Videos (YouTube tab) } \\
\text { Photos } \\
\text { Favourite Pages } \\
\text { Links }\end{array}$ & $\begin{array}{l}\text { Self-description } \\
\text { Slogan } \\
\text { Website URL } \\
\text { Date of joining } \\
\quad \text { YouTube } \\
\text { Date of last sign in } \\
\text { Videos } \\
\text { Vlog } \\
\text { Subscriptions }\end{array}$ \\
\hline 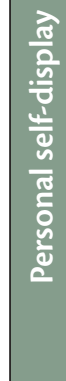 & & $\begin{array}{l}\text { Gender } \\
\text { Age } \\
\text { Mood } \\
\text { Interests } \\
\text { Heroes } \\
\text { Zodiac Sign } \\
\text { Occupation } \\
\text { Ethnicity } \\
\text { Marital status }\end{array}$ & & $\begin{array}{l}\text { Age } \\
\text { Occupation } \\
\text { Interests \& Hobbies }\end{array}$ \\
\hline
\end{tabular}

Table 1: Avaaz's self description components

All of the sites also include "blog" components - a "vlog" in the case of YouTube and "Notes" in the case of Facebook - which allow Avaaz to focus on particular issues, actions, and campaigns. This introduces a temporal element to the description of the organization. While the "blurb" and "mission" statements are fixed in time, blog posts are archived in reverse chronological order, showing which issues and events are dominant at each point in time. In addition, Facebook and MySpace include a "status update" component, which presents what the organization is thinking of "now" or in "real-time". 
All of the platforms help the organization to construct a multimedia image by uploading photographs and videos. These multimedia components can be broadly categorized into "advertisements", consisting of posters, magazine ads, or television spots produced by Avaaz, and "recordings", i.e., material recording offline actions organized by Avaaz and depicting its supporters and campaigners.

Blogs also allow for the emergence of individual voices, which personalize the image of the organization. The posts on the main website are signed with the name of the campaigner who wrote them, while vlog posts on YouTube are uploaded by individual accounts.

Personalization is also stronger on Facebook, MySpace, and YouTube, where the organization's profile includes more information about Avaaz's tastes and interests. These refer to the types of causes it pursues, including its interests and hobbies, as well as "heroes". They also comprise its "Subscriptions" on YouTube - a list of channels that Avaaz is subscribed to and "Favourite Pages" on Facebook. While the latter refer almost exclusively to other causes or to organizations fighting for similar issues, Avaaz's YouTube subscriptions also include channels of musicians and news organizations, mixing cultural with more political references.

As the table shows, Avaaz presents a more personal image on YouTube and MySpace. On YouTube, Avaaz is a 28-year old campaigner whose interests and hobbies include human rights, justice, and environmentalism. On MySpace, Avaaz describes itself as a 35-year old single woman, born under the Capricorn zodiac sign, whose mood is "hopeful". The self-description also includes a long list of interests and "heroes", such as Nelson Mandela and Mahatma Gandhi. The design of the MySpace page and the YouTube channel is more lively and colourful, as opposed to the clean white background of both Facebook and the main website.

A possible explanation for this greater personalization on YouTube and MySpace refers to the architecture of each platform and the potential that they offer for organizational communication. In that respect, Facebook makes a distinction between profiles, groups, and "pages". Profiles represent individuals, while "pages" are created by organizations, bands, and public figures to communicate with their "fans". "Pages" are public and listed on Google and other search engines. While any individual user can launch a group, "pages" are established only by official representatives of the entities in question. These produce content, but are not personally visible on the "page". Facebook pages make a clear distinction between the official voice of the organization and the voice of its "fans", by separating the "Wall" into two tabs, one with posts by Avaaz, the other including comments from its "fans". Thus, while the Avaaz main website and its Facebook page are tailored to represent Avaaz as an organization, its MySpace profile and YouTube channel follow a design that suits both individuals and organizations.

\section{Display of connections}

The "surface" of identity includes not only self-description, but also the display of connections to supporters and peers. As seen in Table 2, these include the organization's "fans" on Facebook", "friends" on MySpace, as well as subscribers and "friends" on YouTube. As of the 
$15^{\text {th }}$ of August 2009, Avaaz had 57,792 "fans" on Facebook, 6,876 "friends" on MySpace, as well as 2,244 subscribers and 320 "friends" on YouTube. These comprised both individuals and organizations. While on these platforms, supporters were visible with names or nicknames, photographs or avatars, and other types of information, the Avaaz website identifies supporters only through their comments in the "Comments and Advice" application. In other words, Facebook, MySpace, and YouTube offer Avaaz supporters a more prominent place in the organization's image (This is no longer the case for Facebook "pages" - please see endnote 1 for further details.).

\begin{tabular}{|c|c|c|c|}
\hline Main Website & MySpace & Facebook & YouTube \\
\hline $\begin{array}{l}\text { Comments to blog } \\
\text { Comments to "Com- } \\
\text { ments and Advice" } \\
\text { section } \\
\text { Visual features showing } \\
\text { number of people } \\
\text { donating money or } \\
\text { signing petitions } \\
\text { Press Highlights }\end{array}$ & $\begin{array}{l}\text { Comments to main } \\
\text { page } \\
\text { Comments to blog } \\
\text { posts } \\
\text { Friends (including "Top } \\
\text { Friends") } \\
\text { "Causes" application }\end{array}$ & $\begin{array}{l}\text { Fans' wall comments } \\
\text { Fans' comments to } \\
\text { other fans } \\
\text { Discussions } \\
\text { Links } \\
\text { "Like" comments } \\
\text { Video ratings } \\
\text { Views } \\
\text { Fans } \\
\text { "Causes" application }\end{array}$ & $\begin{array}{l}\text { Comments to channel } \\
\text { Subscribers } \\
\text { Friends } \\
\text { Number of subscribers } \\
\text { Number of channel } \\
\quad \text { views } \\
\text { Ranking (in terms of } \\
\text { subscriptions) } \\
\text { Video ratings }\end{array}$ \\
\hline
\end{tabular}

Table 2: Display of Connections

However, the different architectures of the three platforms provide these connections with different meaning and stratification. On Facebook, any registered user could become a "fan" of Avaaz automatically, while the term "fan" pointed to a less equal relationship than the one between "friends". Nevertheless, since August 2009, the design of Facebook pages has changed and now registered users can simply "like" a page. This suggests an even weaker relationship than the one between an organization and its "fans". On MySpace, "friend" requests need to be accepted and authorized by Avaaz. MySpace also stratifies "friends", allowing its users to indicate their "top friends". For Avaaz, these were exclusively organizations it is affiliated with or who campaign on similar issues, such as Moveon.org. On YouTube, supporters are stratified into "friends" and "subscribers". The latter have a weaker connection with the organization, as subscribers simply get notified when a new video is uploaded to the channel they have subscribed to. "Friends", on the other hand, can engage in more forms of communication with the organization. These distinctions between "friends" and "top friends" on MySpace and between "friends" and "subscribers" on YouTube - are thus being used by the organization strategically to place itself in specific positions within its web of connections.

The platforms also generate information automatically, which helps to gauge the response of the public to the organization. The number of "fans", "friends", or "subscribers" hints at the popularity and size of the organization, while video ratings reveal the attrac- 
tiveness of its content. The main website also employs visual features to show the number of people who have signed a petition or donated money to a campaign. MySpace and Facebook further comprise a "Causes" application, showing which causes Avaaz has campaigned about and how many people have responded to its calls to take action. This helps participants to gain a sense of the broader activist community in which they are involved and to develop a "shared awareness" (Shirky, 2011).

Finally, comments by "friends", "fans", or simply users of the site are present in all the examined spaces. These can be posted on the organization's "Wall" or as a response to blog or vlog posts. Comments revolve around specific themes, some common on all platforms, others appearing more on specific ones. The content analysis showed that on all the examined spaces, supporters mainly thank and congratulate the organization for its work and express their solidarity. Of the 400 messages that were analysed, 221 included content of this kind ${ }^{2}$. More specifically, 52 messages on Facebook, 34 on MySpace, 52 on YouTube, and 63 on the Avaaz website included some form of thanks, congratulations, or support.

As a predominantly content-sharing site, user interaction on YouTube centres on the content uploaded on the platform. Therefore, comments of congratulations on YouTube refer equally to the videos produced by Avaaz and to its work in general. Thus, from these 52 messages of thanks and congratulations, 30 focused on its channel and videos and 5 referred to both Avaaz's work and YouTube channel. On MySpace, supporters expressed their affiliation to Avaaz with "Thanks for the Add" comments. Such comments were unique to MySpace and can be considered as a result of its "friending" norms. Other comments made a more direct contribution to the agenda of Avaaz by providing suggestions for new campaigns. These were mostly present on the Avaaz website, which asked supporters explicitly for their advice.

There were very few comments that included criticism, and "flaming" occurred only on YouTube. The fact that any user can post on Avaaz's YouTube wall partly explains the slightly higher number of "flaming" messages on this space. Still, in relation to the comments on individual videos, "flaming" was at a minimum on the YouTube channel. Although not analysed for the purposes of this article, the page of the "Clash of Civilizations" video, a controversial Avaaz video that earned a YouTube award in 2007, attracted many anti-Semitic and Islamophobic comments. Such posts are virtually non-existent on the other platforms.

Supporters also used the Avaaz pages as a platform to make their own general statements or to promote their own causes. MySpace included the highest number of such messages, as nearly half of the analysed comments (49) were promotional messages. The majority of these - 34 in number - included some form of self-promotion that had no relation to the causes advocated by Avaaz. Many "friends" provided links to their profiles, asking users to check out their music. Again, this reflects the norms of MySpace, where the promotion of music constitutes a predominant activity.

Still, the architecture of all the platforms allows Avaaz to maintain control of its image. The layout of profiles on social networking and content sharing platforms is designed in 
a way that makes the voice of the profile creator more visible and more dominant. Thus, although supporters are free to post their comments and at times almost take over the "wall" with concerns that are not related to Avaaz, their contributions are featured in specific parts of the profile; i.e., the "wall" and the "Comments and Advice" section. Avaaz's voice is more distinct and more authoritative in the other parts of the profile, allowing it to maintain a coherent organizational image across every platform.

\section{Platforms as sites of engagement, bonding, and group identity}

The investigation of web platforms as sites of interaction showed that every platform facilitated communication between the Avaaz core team and individual supporters. Communicative actions between this pair can be identified based on two categories: affiliation and interaction. The former include "friend" requests on MySpace and YouTube, to which Avaaz can respond by accepting. They also comprise becoming a "fan" on Facebook and a "subscriber" on YouTube, which do not require authorization from Avaaz. They are thus a form of one-way communication between users and the platform, which is authorized to "speak" on behalf of the organization. On the main website, supporters can become affiliated by subscribing to the Avaaz email alerts list. Affiliation is important for providing supporters with access to the communication occurring on the platform. This is particularly the case on MySpace, where supporters need to be a "friend" of the organization in order to post on its wall or send personal messages. It is also the first step through which individuals become part of the "public" generated by the organization, an audience to which Avaaz can easily broadcast messages.

Private and direct interaction between supporters and Avaaz mainly involves sending messages to Avaaz through the platforms. On MySpace, "friends" can also instant message Avaaz. The main website, on the other hand, includes a contact form that systematizes the process of feedback from supporters. This multiplies the avenues through which the organization can receive and respond to messages and facilitates the process of "servant leadership". However, it also increases the workload of the core team. As a result, not all enquiries are answered directly, according to the Avaaz website: "While we can't respond to every message, we do our best to review them all, and we take them very seriously."

Furthermore, all of the examined spaces provide opportunities for private and direct communication between supporters and their own personal networks. The main website includes a "Tell Your Friends" application, where supporters can input automatically email addresses from their address book and message their friends about actions they have undertaken with Avaaz. On Facebook, MySpace, and YouTube, supporters can suggest the profile to their "friends", share content from the Avaaz profile, or embed a link to the YouTube channel in personal communications. These applications turn supporters into communicators of the Avaaz message in their own right. They therefore make the most of the "viral" properties of websites and social networking sites by facilitating the spread of infor- 
mation within existing social networks. In terms of bonding, such features consolidate the links between supporters and their contacts.

In contrast, private communication among individual supporters is almost non-existent on most of these spaces. On Facebook, MySpace, and YouTube, this type of communication can only happen through the users' individual profiles. However, each platform places certain restrictions on the interaction among individuals who are not "friends" with each other. For instance, Facebook cautions those who communicate with a high number of "non-friends" as part of its anti-spam policy. The fact that individuals may be "fans" of the same page or "friends" of the same organization does not relax these rules of private oneto-one communication.

Nevertheless, supporters are offered many options to communicate with others in public. They can post comments on every space occupied by Avaaz, rate videos on YouTube and Facebook, give "kudos" on MySpace and "thumbs up" on Facebook. In addition, Facebook "fans" can start and respond to discussions that are listed publicly on the website. But although public comments can be viewed by everyone, they are written with different audiences in mind.

The textual analysis of comments showed that supporters tended to position themselves as individuals. While statements and comments of promotion addressed a general public, most messages of thanks and congratulations addressed Avaaz as a separate entity. The following comments are typical examples:

\footnotetext{
I have been a member on email, for a long time, and fully believe that what you are doing globally is unreal! Keep up the great work!

(Posted on Facebook by Suzanne Fox Kennedy, July 16, 2009)

Thank you for the important work you are doing. It is an impressive network that you have built and I like doing my bit to get it to sustain.

(Posted on www.avaaz.org by Kirkara from Germany)
}

At the same time, in the majority of messages giving thanks and congratulations or expressing solidarity, individuals presented themselves as part of an abstract community of Avaaz supporters. For instance, notice the use of "us" in the comments that follow:

Thanks for empowering us computer activists.

(Posted on Facebook by Pamela Disque Hall, July 27, 2009)

hope and strength come in every mail you send us

(Posted on Facebook by Lola Martinez Fornons, July 21, 2009)

Thanks for giving us a chance to have a voice to fight for the important issues facing our world. Congratulations on the successes and keep up the good work!

(Posted on www.avaaz.org by Linda from Australia) 
The first comment expresses a sense of belonging in a community of "computer activists". The latter two point to an "us" that is constituted through communication with Avaaz and comprises the recipients/audiences of its emails. In other words, these comments imply an abstract sense of "we" that is built through people's common affiliation to Avaaz rather than through direct ties with each other.

On Facebook, supporters' comments were often implicitly addressed to their own social networks. Take for instance the following comment:

Please join this powerful community to help make our world a better place and save our fragile environment, than $x$ :)

(Posted on Facebook by Sean Corrigan, August 12, 2009).

This type of comment was very rare on other platforms and can be considered a result of Facebook's architecture, whereby users' comments on "pages" can also appear on their own personal profiles and on their "friends" newsfeeds. This allows "fans" to use the wall of the Avaaz page in order to promote the organization to their own networks.

At the same time and on all platforms, comments addressing individual supporters of Avaaz were almost non-existent. This compounds the lack of interpersonal interaction among Avaaz supporters and limits the potential of these spaces for the development of strong interpersonal ties among participants.

\section{Conclusion}

Representing a hybrid form of transnational activism (Chadwick, 2007), Avaaz uses the Internet extensively to "bring people-powered politics to international decision-making" (www.avaaz.org). This article explored the organization's website and its presence on Facebook, MySpace, and YouTube, focusing on the affordances of these platforms for engagement, bonding, and identity-building.

The findings show that all of the examined spaces allow the organization to construct an image that is complex, multimedia, and dynamic, including features that offer real-time or regularly updated information. However, the balance between the individual and the collective, the personal and the organizational is different on every platform.

Designed as forms of "organizational" communication, the Avaaz website and the Facebook page were tailored to represent Avaaz as an organization. On MySpace and YouTube, in contrast, Avaaz displayed a more playful image, describing itself as a person rather than an organization. Governed by a logic that favours individual creativity (Fenton \& Barassi, 2011), the design of these two platforms is more suited to presenting a personal rather than collective image. Still, Avaaz used design elements creatively to signal its organizational status. On MySpace, for example, the organization employed the "top friends" application in order to locate itself more clearly within a peer network of similar or partner organizations. 
Furthermore, individual voices and images are more present on social media platforms than on the organization's website. Blog posts are written and signed by individual staff members, while "fans", "friends", and supporters are allowed some visibility through their comments, avatars, and photographs. Thus, supporters become co-producers of the organization's image and can use its profile for their own purposes. This is particularly the case on MySpace, where the wall is used as a platform for self-promotion and for causes that have nothing to do with Avaaz.

Still, the design, rules, and regulations of each platform ensure the organization's control over its image and "display of connections" (Livingstone, 2008). For instance, it can choose not to accept specific "friend" requests or to delete "fans" and "friends". The comments always appear in a dedicated part of the profile, while platforms like Facebook make it easier to distinguish between the voices of the organization and its users, by separating the comments of the profile creator from those of the "fans". This allows Avaaz to be the dominant voice on its profile and to maintain a consistent and coherent image on all of the examined spaces. Thus, while the danger of individual voices stifling the collective ones does exist (Fenton \& Barassi, 2011), the examined profiles balance the individual and the collective in a manner that satisfies the demands of current activism for both personalization and organizational coherence (Bennett \& Segerberg, 2011).

In terms of bonding, the four platforms offer opportunities for direct one-to-one communication between Avaaz and its supporters, either through public comments or more private emails and feedback forms. They thus operate as "listening posts" that facilitate Avaaz's "ethic of servant leadership", as they provide the organization with more opportunities to garner feedback from its members.

The four platforms also help the organization to utilize the "viral" properties of the web, by helping supporters to message their own networks about Avaaz. Mobilization to action can scale up quickly, as information is diffused through existing networks of contacts. This multiplies the reach of the organization's message, as social media users can easily become the targets of mobilization efforts. Communication through social media platforms can also lower the barriers to entry and increase people's motivation to participate, as "it is your friends or relatives that hold you to your promises" (Klandermans, 1997, p. 25).

However, interpersonal interaction among Avaaz's individual supporters is kept at a minimum, limiting the potential of these platforms for the development of strong ties among the Avaaz membership base. Eaton (2010) observed similar issues in his analysis of MoveOn, noting how in the absence of contact between MoveOn members, the organization attempted to manufacture a sense of community by employing particular modes of address and rhetorical images in its email communication with its members. Maintaining spaces where members can interact with each other and build strong ties is resource intensive, while participation challenges the control of the organization over its message (Fenton \& Barassi, 2011; Gillan et al., 2009). Political organizations often have to make a choice between control and interaction, between broad mobilization and deep participa- 
tion (Beutz Land, 2009). Avaaz's strategy of quick mass mobilization means that it devotes fewer resources on developing the direct interaction among members. In an interview with Beutz Land, Ricken Patel, Executive Director of Avaaz, noted that while Avaaz initially thought of implementing a more participatory model on its website, it settled instead for a model of centralized broad mobilization with regular consultation of the membership base. The rationale was "that organizations are successful if they offer people what they need, and what people need is not the opportunity to become more involved but rather assistance in becoming more effective in the things that they do" (Beutz Land, 2009, p. 221).

This does not mean that ties among Avaaz supporters are non-existent. Rather, Avaaz members are connected by a more abstract sense of community that is constructed through their common affiliation to the organization (Flanagin et al., 2006). The textual analysis of comments on the four platforms showed that users tended to address most of their comments towards Avaaz, who they perceived as a separate entity. They nonetheless expressed feelings of belonging to an abstract "imagined community" (Anderson, 1991) of Avaaz supporters, brought together by the actions organized by Avaaz.

The comments left by supporters on these platforms are mostly messages of solidarity, thanks, and congratulations. However, the themes of messages, and thus the object around which solidarity is built, differ according to the norms of each platform. On MySpace, the wall is taken over by "Thanks for the add" comments, while on YouTube congratulations centre on the videos produced by the organization rather than its work. Therefore, on YouTube, a shared identity is also constructed around the video content produced for the campaign.

Still, mobilization is mainly for simple online actions, which can be seen as a form of "clicktivism" or "slacktivism" (Gladwell, 2010; Morozov, 2011). This raises the question of whether such spaces have the ability to strengthen political participation. Indeed, of the people participating in online action, only a small per cent become more involved in other Avaaz activities (Beutz Land, 2009). Yet, in the comments of thanks and support examined in this study, users were regularly expressing a sense of empowerment through the simple online actions they were taking with Avaaz. Studies investigating the perspective of lay supporters are scarce in this field. This does not allow us to draw solid conclusions about the impact of social media on political participation. To call such people "clicktivists" or "slacktivists" without prior research is to unfairly dismiss their opinions and experiences.

Therefore, future studies should explore this topic from the point-of-view of lay supporters. The findings of this study and its conceptualization of web platforms as "sites" and "surfaces" (Taylor \& van Every, 2000) of bonding and group identity can hopefully constitute a stepping stone in this direction. 


\section{Notes}

1. At the time of the fieldwork (August 2009), registered Facebook users could "Become a Fan" of a page. "Fans" were visible on the page with their photographs and registered names (in the same way that "Friends" are displayed on Facebook profiles). Since then, the design of Facebook pages has changed. Registered users can "Like" a page, so the term "fan" is no longer used. In addition, the people who "like" a page are not personally visible on the page. However, registered Facebook users can now see which of their friends "like" a specific page.

2. It is worth noting here that messages could fulfil different functions. For instance, they could both give congratulations to Avaaz and include some form of self-promotion.

\section{References}

Anderson, B. (1991). Imagined Communities: Reflections on the Origin and Spread of Nationalism. London: Verso.

Andrejevic, M. (2011). Social Network Exploitation. In Z. Papacharissi (ed.), A Networked Self: Identity, Community, and Culture on Social Network Sites (pp. 82-101). London and New York: Routledge.

Baym, N. (2010). Personal Connections in the Digital Age. Cambridge: Polity Press.

Bennett, L. W. (2005). Social Movements beyond Borders: Understanding Two Eras of Transnational Activism. In D. della Porta, \& S. Tarrow (eds.), Transnational Protest and Global Activism (pp. 203-226). New York and Oxford: Rowman \& Littlefield Publishers.

Bennett, L.W., \& Segerberg, A. (2011). Digital media and the personalization of collective action. Information, Communication \& Society, 14(6): 770-799.

Beutz Land, M. (2009). Networked Activism. Research Paper \#13, New York Law School Legal Studies Research Paper Series 09/10. Retrieved, January 21, 2012 from: http://papers.ssrn.com/sol3/papers. cfm?abstract_id $=1475423$

Bloomfield, B.P., Latham, Y., \& Vurdubakis, T. (2010). Bodies, technologies and action possibilities: When is an affordance? Sociology, 44(3): 415-433.

Boyd, A. (2003, 17 July). The web re-wires the movement. The Nation. Retrieved, August 29, 2009 from: http://www.thenation.com/doc/20030804/boyd

Boyd, D. (2006). Friends, friendsters, and top 8: Writing community into being on social network sites. First Monday, 11(12). Retrieved, October 1, 2008 from: http://www.uic.edu/htbin/cgiwrap/bin/ojs/index. $\mathrm{php} / \mathrm{fm} /$ article/view/1418/1336

Chadwick, A. (2007). Digital network repertoires and organizational hybridity. Political Communication, 24: 283-301.

Chadwick, A. (2009). Web 2.0: New challenges for the study of e-democracy in an era of informational exuberance. J/S: Journal of Law and Policy for the Information Society, 5(1): 1-32.

della Porta, D., \& Mosca, L. (2005). Global-net for global movements? A network of networks for a movement of movements. Journal of Public Policy, 25(1): 165-190.

Donath, J. (2008). Signals in social supernets. Journal of Computer-Mediated Communication, 13: 231-251.

Eaton, M. (2010). Manufacturing community in an online activist organization. Information, Communication \& Society, 13(2): 174-192.

Etzioni, A., \& Etzioni, O. (1999). Face-to-face and computer-mediated communities. A comparative analysis. The Information Society, 15: 241-248.

Fenton, N., \& Barassi, V. (2011). Alternative media and social networking sites: The politics of individuation and political participation. The Communication Review, 14(3): 179-196. 
Flanagin, A.J., Stohl, C., \& Bimber, B. (2006). Modelling the structure of collective action. Communication Monographs, 73(1): 29-54.

Foot, A.K., \& Schneider, S.M. (2006). Web Campaigning. Cambridge, Massachusetts and London, England: The MIT Press.

Gueorguieva, V. (2008). Voters, MySpace, and YouTube: The impact of alternative communication channels on the 2006 election cycle and beyond. Social Science Computer Review, 26(3): 288-300.

Gillan, K., Pickerill, J., \& Webster, F. (2008). Anti-War Activism: New Media and Protest in the Information Age. Basingstoke and New York: Palgrave Macmillan.

Gladwell, M. (2010, October 4). Small Change: Why the revolution will not be tweeted'. New Yorker. Retrieved, July 7, 2011 from: http://www.newyorker.com/reporting/2010/10/04/101004fa_fact_ gladwell?currentPage $=$ all

Grimes, J., Jaeger, P., \& Fleischmann, K. (2008). Obfuscatocracy: A stakeholder analysis of governing documents for virtual worlds. First Monday, 13(9). Retrieved, September 30, 2008 from: http://www.uic. edu/htbin/cgiwrap/bin/ojs/index.php/fm/article/viewArticle/2153/2029

Holmes, D. (2005). Communication Theory: Media, Technology and Society. Los Angeles, London, New Delhi and Singapore: Sage Publications.

Hutchby, I. (2001a). Conversation and Technology: From the Telephone to the Internet. Cambridge: Polity Press.

Hutchby, I. (2001b). Technologies, texts and affordances. Sociology, 35(2): 441-456.

Karpf, D. (2009). The MoveOn effect: Disruptive innovation within the interest group ecology of American politics. Thesis excerpt. Retrieved, August 30, 2009 from: http://davekarpffiles.wordpress.com/2009/03/ moveon.pdf

Kavada, A. (2009). Email lists and the construction of an open and multifaceted identity: The case of the London 2004 European Social Forum. Information, Communication and Society, 12(6), 817-839.

Kavada, A. (2010a). Between individuality and collectiveness: Email lists and face-to-face contact in the Global Justice Movement. International Journal of E-Politics, 1(1), 41-56.

Kavada, A. (2010b). Activism transforms digital: The social movement perspective. In M. Joyce (ed.), Digital Activism Decoded: The New Mechanics of Change (pp. 101-118). New York \& Amsterdam: International debate education association.

Livingstone, S. (2008). Taking risky opportunities in youthful content creation: Teenagers' use of social networking sites for intimacy, privacy and self-expression. New Media \& Society, 10(3), 393-411.

Morozov, E. (2011). The Net Delusion: How Not to Liberate the World. London: Allen Lane, An Imprint of Penguin Books.

Noveck, B.S. (2005). A democracy of groups. First Monday, 10(11). Retrieved, November 7, 2005 from: http://www.uic.edu/htbin/cgiwrap/bin/ojs/index.php/fm/article/view/1289/1209

O'Reilly, T. (2004). The architecture of participation. Retrieved, December 30, 2008 from: http://www.oreillynet.com/pub/a/oreilly/tim/articles/architecture_of_participation.html

Papacharissi, Z. (2009). The virtual geographies of social networks: A comparative analysis of Facebook, Linkedln and ASmallWorld. New Media \& Society, 11(1-2): 199-220.

Segerberg, A., \& Bennett, L.W. (2011). Social media and the organization of collective action: Using Twitter to explore the ecologies of two climate change protests. The Communication Review, 14(3): 197-215.

Shirky, C. (2011). The political power of social media: Technology, the public sphere, and political change. Foreign Affairs, 90(1): 28-41.

Snow, D. (2001). Collective identity and expressive forms. Paper posted at the eScholarship Repository, University of California. Retrieved, March 20, 2008 from: http://repositories.cdlib.org/csd/01-07 
Article: Engagement, bonding, and identity across multiple platforms

Stanoevska-Slabeva, K. (2002). Toward a community-oriented design of internet platforms. International Journal of Electronic Commerce, 6(3), 71-95.

Taylor, J.R., \& Van Every, E.J. (2000). The Emergent Organization: Communication as Its Site and Surface. Mahwah, New Jersey and London: Lawrence Erlbaum Associates.

Van Zoonen, L., Muller, F., Alinejad, D., Dekker, M., Duits, L., van Romondt Vis, P., \& Wittenberg, W. (2007). Dr Phil meets the candidates: How family life and personal experience produce political discussions. Critical Studies in Media Communication, 24(4): 322-338.

Van Zoonen, L., Vis, F., \& Mihelj, S. (2010). Performing citizenship on YouTube: Activism, satire and online debate around the anti-Islam video Fitna. Critical Discourse Studies, 7(4): 249-262.

Anastasia Kavada

PhD, Senior Lecturer

Communication and Media Research Institute (CAMRI)

School of Media, Arts \& Design

University of Westminster, United Kingdom

A.Kavada@westminster.ac.uk 